\title{
El inicio de la economía castiza española: la economía de la Regencia
}

\author{
Juan Velarde Fuertes
}

Arbor CLX, 630 (Junio 1998), 183-213 pp.

Desde 1875 a 1950 se construyó en España un modelo de política económica que es el que ahora mismo se pretende superar. Se basaba en un proteccionismo creciente, una moneda fiduciaria, una huida de la economía libre de mercado, la admisión de déficit presupuestario y un populismo social compensador. Se pretende explicar cómo este modelo castizo se inició con fuerza durante la Regencia, al intentar imitar el modelo alemán, al ser orientado por las ideas de Cánovas y al actuar como catalizador el propio Desastre de 1898. Se concluye con la comprobación de que esta situación creada por la Regencia más nos alejó que nos acercó a la economía de los países más desarrollados.

Desde noviembre de 1885 a mayo de 1902 transcurre en España la Regencia de María Cristina de Habsburgo-Lorena. En esta larga etapa en la que la responsabilidad ile la Jefatura del Estado recae en la Reina María Cristina, tienen lugar acontecimientos esenciales en la Historia de España. Políticamente, quedamos barridos, tras los choques sucesivos con Alemania y los Estados Unidos, del Pacífico y del Caribe. Ese cambio esencial va acompañado de uno no menos importante en nuestra vida cultural. Basta decir que la generación del 98 y el modernismo dan en ella sus primeros pasos. 
Ambos cambios, político y cultural, muy de fondo, tienen un acompañamiento asimismo en el económico. Buena parte de la realidad económica nacional creada hasta el viraje aperturista de 1959, cuando se inicia el gran cambio que conducirá a la incorporación al ámbito comunitario de 1986, además del ingreso en el Sistema Monetario Europeo de 1989 y a la participación, con el grupo de los once, en la tercera fase de la Unión Económica y Monetaria, se fraguó precisamente en la Regencia. Por eso conviene señalar, sucesivamente, tres cuestiones. La primera, las circunstancias económicas internacionales que reinaban cuando, tras la década de Alfonso XII, el trono va a ser administrado durante dieciséis años por la reina María Cristina $y$, dentro de ellas, ha de analizarse con especial énfasis, lo que sucedió en Alemania, porque se convirtió en faro para nuestra política económica. La segunda, el peso especialísimo de las ideas de Cánovas del Castillo. La tercera, lo que un economista puede opinar del Desastre. Aparte, y conviene insistir en ello, como algo que empapa este triple enfoque, debe destacarse que con todo estc, lu que se observa, con fuerza creciente, es la construcción a lo largo de este periodo del entramado que ha pasado a recibir el nombre de economía castiza española

\section{Los modelos extranjeros}

Cuando María Cristina de Habsburgo pasa a ocupar la Jefatura del Estado, como Reina Regente, el mundo se encontraba sumido en una situación depresiva bien conocida. Kondratief señaló que la II onda larga del capitalismo creado por la Revolución industrial inicia su derrumbamiento en los años 1870-75 ${ }^{1}$. En 1885, la crisis era general $^{2}$. En los Estados Unidos todo esto había promovido innumerables tensiones sociales, como la que se desarrolló entre los granjeros y las empresas ferroviarias que, se decía, arruinaban con sus altas tarifas a los primeros, mientras favorecían, con otras muy reducidas, a las grandes empresas capitalistas, que comenzaban a agruparse en grandes conglomerados o "trusts", desde el del petróleo al del azúcar ${ }^{3}$. Tampoco podía olvidarse cómo acentuaban las tensiones los sindicatos obreros - la American Federation of Labor es de 1880 - , enfrentándose a los empresarios con huelgas tan considerables como la del acero de 1882, la del carbón de 1884, la de los ferrocarriles de 1886, y algaradas como las de la costa del Pacífico, de 1885, contra la llegada de inmigrantes chinos. En la primavera de 1884, añadamos que la quiebra 


\section{El inicio de la economía castiza española}

de dos empresas bancarias, provocó una crisis bursátil que concluyó en graves alteraciones del sistema crediticio. Concretamente, 1885 fue en Norteamérica un año de depresión y paro.

En Gran Bretaña reina la que se llamaría poco después «la gran depresión". Joseph Chamberlain, para atenuar las consecuencias del paro, y como resultado, muy posiblemente, también de la política populista de Bismarck, pretende que los municipios comiencen a desarrollar programas de obras de utilidad pública. La condensación de problemas acabaría provocando en 1890 la crisis de la Banca Baring Brothers \& $\mathrm{Co}$, que pudo ser superada gracias a una intervención concertada del Banco de Inglaterra y de las principales entidades bancarias de la City. En 1883 se había fundado la Fabian Society. En 1884, la Misión del Ejército de Salvación de socorro a las prostitutas, cuyo número había crecido vertiginosamente a impulsos de la crisis, comienza a hacer oír su trompetería militar en Whitechapel. En 1889, una dura huelga de estibadores londinenses motiva que el cardenal Manning se ponga del lado del proletariado desvalido, como un preludio de la Rerum novarum de Leon XIII, que se publicaría el 15 de mayo de 1891.

En Francia, en 1882, se había iniciado una crisis económica importante con la suspensión de pagos del Banco de Lyon y del Loira. Pronto se propagó, a través de la crisis Bontoux a la Unión General. Ésta se había fundado en 1878 y parecía patrocinada por la opinión legitimista afín al Conde de Chambord y por la opinión católica, sin excluir al Vaticano. La había impulsado el ingeniero Bontoux, que había trabajado en el mundo ferroviario europeo creado por los Péreire y los Talabot. Esta institución financiera había recogido fondos de «los hidalgüelos provincianos, de los curas de pueblo, de las señoritas solteronas, de los pequeños comerciantes y del ahorro campesino" ${ }^{4}$. De ahí la crisis se propaga a buena parte de los bancos de negocios que, en gran número, habían surgido en Francia a partir del período 1871-73, a causa de una disposición que permitía crear una institución de crédito con el desembolso de sólo la cuarta parte del nominal de sus acciones. Esta depresión de 1882 comenzó a llegar a la indüstria en 1883, a las actividades de construcción ferroviaria en 1884 y, finalmente, también en 1883 a la siderurgia que se había comenzado a localizar en su expansión en zonas i usteras - Bayona, Saint-Nazaire, Caen- para aprovechar las ventajes del transporte marítimo de los minerales. Como consecuencia de esta crisis, el Comité des Forges se ve obligado a transformarse, en 1887-1888, de simple gremio de estudio en central siderúrgica ${ }^{5}$. La Compañía del Canal de Panamá, que había 
iniciado sus trabajos en 1881, encuentra en 1886 obstáculos que no puede superar desde el punto de vista financiero. En enero de 1889 se producirá su bancarrota, iniciándose el famoso escándalo de Panamá.

El contraste se encontraba en Alemania. Es preciso exponer esto con alguna mayor amplitud, precisamente para entender la política económica española. Tras derrotar a los franceses en Sedán en 1870, Berlín consigue en 1879 -cicatrizadas las heridas de Sadowa-, una alianza defensiva con el Imperio austriaco que se ampliará en 1882 a una Italia irritada por la conquista en 1881 de Túnez por Francia. En 1884 Alemania adquiere el Sudoeste africano, y en 1885 choca con España por el conflicto de la Micronesia, en el Pacífico. Al mismo tiempo, desde 1883 - seguro de enfermedad-, a 1889 -seguro de vejez e invalidez - pasando por 1884 - seguro de accidentes de trabajo-, se ponen en marcha los seguros sociales obligatorios bismarckianos que crean un modelo mundial de protección social que llegará hasta que aparezca en la II Guerra Mundial el modelo alternativo de Beveridge.

Es el momento también de la gran victoria de los proteccionistas gracias a las barreras aduaneras de 1879 , bajo el lema de "protejamos el trabajo nacional en la ciudad y el campo». La Unión Aduanera Alemana - la Zollverein de 1834, abierta hacia el interior, cerrada hacia el exterior, por la que tanto había luchado List- había triunfado al unirse a la creación del Imperio alemán por Bismarck en la Galería de los Espejos del Palacio de Versalles. Con este creciente proteccionismo, surgía aquella soñada nación alemana que había motivado los famosos Reden an die deutsche Nation (Discursos a lá nación alémáná) de Fichte.

Todo se une a un expansionismo político de carácter nacionalista, mientras se busca ocupación para la mano de obra del pueblo alemán. Como ha observado Alberto Hirschman, Alemania pretende emular de algún modo la política del Reino Unido que, tras la polémica de las anticorn laws había perdido gran parte de su agricultura y, por tanto, de su capacidad de autoabastecerse en productos rurales. El Imperio británico, con su gigantesca expansión colonial, su enorme flota mercante y su potente Marina de guerra, podía permitirse ese desprecio a la agricultura. Para lograr una situación parecida, Alemania -y otros muchos pensaron hacer lo mismo-, creyó que también tenía que disponer de colonias, que sostener una fuerte Armada, que subvencionar a una marina mercante -en 1885 eso se hace en favor de empresas armadoras de trasatlánticos- pero; sobre todo, al' no ser tan potente en esto como el Reino Unido, comprendió que era preciso 
atender «a la famosa alianza del acero y el centeno", la que constituyó en el Reich alemán un "pacto entre la industria pesada y los junkers". Dentro de ese modelo juega también un papel central la proliferación de asociaciones empresariales, ya integradas verticalmente, ya cartelizadas: entre 1879 y 1885 habían surgido 76 cárteles $^{6}$.

Esta realidad era tan heterodoxa para la mentalidad de los economistas británicos de entonces como lo eran el proteccionismo y la banca mixta. Arnold Wolfers señalará ${ }^{7}$ que «el movimiento en favor del cártel continuó siendo, hasta la I Guerra Mundial, un asunto específicamente alemán y austriaco; los economistas anglosajones y franceses se ocupan de los cárteles como de algo descarriado, como de un fenómeno extranjero, de origen alemán. A eso se debe que los investigadores científicos de Alemania sintiesen la responsabilidad de iniciar una tarea que desenvolviera, y elaborara, una doctrina relacionada con el cártel».

Inmediatamente, los historicistas y los socialistas de cátedra se apropiaron con júbilo poco oculto de esta institución. Schmoller hablaría de cómo esta organización llevaba hacia una política de desarrollo económico que, a la fuerza, se integraría en algún tipo de dirección estatista, o socialista, de la economía ${ }^{8}$.

Este sendero se comenzó a recorrer con la cartelización obligatoria de la política económica del Kaiser Guillermo II. Franz Newmann, dentro de la cartelización obligatoria de la época, menciona a "los cárteles del carbón y la potasa", así como los "del almidón; fósforos; leche, azúcar de remolacha, navegación interna y canales» ${ }^{9}$. Alfredo Marshall comenzará a integrar todo esto en la economía neoclásica en 1919 en su Industry and Trade ${ }^{10}$. Actualmente, la comprensión del fenómeno vendrá de la mano de George Stigler a partir de su artículo $A$ theory of oligopoly ${ }^{11}$.

Este entusiasmo neohistoricista y socialista de cátedra, se acabaría por traspasar al nacionalsocialismo, quien, por la Ley de 15 de julio de 1933, concedía al ministro de Economía amplias facultades para decidir la cartelización obligatoria, explicándose esto por «la severa depresión que se cierne sobre la economía alemana (que) ha afectado con gran intensidad a las ramas industriales que tienen una capacidad productiva muy superior a las posibilidades actuales de venta. La intensa competencia y el bajo nivel de precios que de ello resulta... nos han llevado a un punto tal que amenaza con la ruina de emprésăs valiósós para nuestra economía nacional" ${ }^{12}$. Esta öbligatoriedad, dice Claire Rusell ${ }^{13}$, al ser ayudada por la soberanía del Estado, "proporciona al cártel un poder que no hubiese sido capaz de alcanzar voluntariamente". 
Debido a esto, sabemos, como indica Ervin Hexner, que aquello que podría llamarse técnicamente cártel, por serlo realmente, ha sido sustituido por las autoridades "por palabras menos significativas, tales como asociaciones, oficinas, federaciones, ententes, convenciones y convenios..., eufemismos que son divertidamente transparentes para quienes conocen el significado de las palabras empleadas" ${ }^{14}$.

Agreguemos que en Alemania, en 1848, había nacido una creciente y por ello cada vez más potente Banca mixta. La reconstitución de la Schaffhausen, que se dedicó inmediatamente a la industrialización de Alemania, fue pronto seguida, en 1852, por la Diskontogesellschaft $y$, en 1853, con domicilio social en Darmstadt - a causa de las condiciones favorables dispuestas por el Gran Ducado de Hesse para que estas organizaciones crediticias se organizasen sin trabas-, por el Bank für Handel und Industrie. Como señala Åkerman sobre esta situación alemana, "esta mejor adaptación del crédito a la actividad de las empresas industriales liberó las fuerzas latentes del progreso" ${ }^{15}$.

Pues bien; en medio de esa situación, la producción industrial alemana crecería de 1890 a 1913 a una tasa sólo superada por Rusia, como muestra el cuadro siguiente ${ }^{16}$ :

\begin{tabular}{|l|c|l|c|}
\hline \multicolumn{4}{|c|}{ TASAS ANUALES Y PORCENTUALES DE INCREMENTO DEL fNDICE DE } \\
PRODUCCIÓN INDUSTRIAL (IPI), 1890-1913 \\
\hline \multicolumn{1}{|c|}{ Países } & Tasas & \multicolumn{1}{c|}{ Países } & Tasas \\
\hline Gran Bretaña & 2,0 & Hungría & 3,4 \\
\hline Francia & 2,1 & Suecia & 4,1 \\
\hline Austria & 2,5 & Alemania & 4,1 \\
\hline Italia & 2,8 & Rusia & 5,1 \\
\hline
\end{tabular}

Alemania lograba mantener, desde tiempo atrás, una tasa de incremento del IPI, que convertía a esta nación, de atrasada, en adelantada. La revolución industrial alemana, a mi juicio, se había iniciado, como muy bien señala Antonio Ramos-Oliveira «en la década de 18301840, y después de 1850 alcanzó su auge... Puede decirse que en aquel decenio penetró en Alemania la industria moderna... La producción manufacturera aumentó con la consiguiente celeridad» ${ }^{17}$. Para eso fue fundamental la ampliación del mercado con la mencionada Zollverein, que se había constituido el 1 de enero de 1834. Había recibido el primer impulso gracias al esfuerzo de Federico List, a partir de su asistencia en abril de 1819 a la reunión fundadora de la Asociación 
El inicio de la economía castiza española

Alemana de Comercio Interior y Exterior, constituida para abolir las barreras internas al tráfico ${ }^{18}$. Schumpeter dirá, con razón: “List vio una nación que forcejeaba presa en las cadenas que le imponía un pasado inmediato miserable; pero vio también las potencialidades económicas de aquella nación" ${ }^{19}$.

Se creó así una complicada base que resultó muy eficaz desde el punto de vista real. Al observar las cifras macroeconómicas se percibe que el proceso expansivo se había convertido, desde luego, en bien visible, de 1861 a 1890 . Las crisis internacionales no parecían afectar demasiado al Imperio germano. Como resultado se observa de qué modo su crecimiento va muy por delante del de otros países occidentales. Sólo Rusia logrará mantener algún tipo de emulación en las tasas de desarrollo logrado a lo largo de la segunda mitad del siglo XIX ${ }^{20}$. Realmente hay que convenir, con $\AA$ kerman ${ }^{21}$ en que "sin miedo a exagerar, la vida económica alemana no conoció ni crisis ni depresiones durante el largo período que va de 1859 a 1873».

Como consecuencia, el crecimiento industrial alemán fue muy fuerte desde 1861, como se observa a continuación.

\begin{tabular}{|l|c|l|c|}
\hline \multicolumn{4}{|c|}{ TASAS ANUALES Y PORCENTAJES DE INCREMENTO DEL INDICE DE PRODUC- } \\
CION INDUSTRIAL (IPI), 1861-1890 \\
\hline \multicolumn{1}{|c|}{ Países } & Tasas & \multicolumn{1}{c|}{ Paises } & Tasas \\
\hline Francia & 1,3 & Hungría & 2,9 \\
\hline Italia & 1,6 & Suecia & 3,4 \\
\hline Zspaña & 2,3 & Alemania & 4,0 \\
\hline Gran Bretaña & 2,4 & Rusia & 4,7 \\
\hline Austria & 2,9 & & \\
\hline
\end{tabular}

Es evidente que en la Regencia las cifras de este acusado desarrollo germano tenían que impresionar mucho, en particular por la humillación a que habíamos sido sometidos por parte de Alemania en el conflicto de la Micronesia.

\section{El peso de Cánovas del Castillo}

Veamos ahora cómo, recogiendo esta rica realidad internacional, articuló Cánovas del Castillo sus decisiones para ordenar de modo permanente, la vida económica, porque bien puede decirse que la eco- 


\section{Juan Velarde Fuertes}

nomía española del siglo XX fue, hasta 1959, hija de la de Cánovas del Castillo. A partir de tal año y hasta, precisamente, 1997, la misma se constituyó como una especie de rectificación a Cánovas. Un siglo después del magnicidio de Santa Águeda, con nuestra incorporación a la tercera fase de la Unión Económica y Monetaria, entra España en una situación tan diferente que bien podríamos decir que el siglo XXI va a ser el que borre definitivamente - salvo quizás en el campo-, la que fue profundísima huella de Antonio Cánovas del Castillo en nuestra economía.

Conviene añadir que, al revisar la vida de Cánovas del Castillo lo veamos casi sobrecogido por la tarea que se le viene encima. Cuando el partido moderado comenzó a degenerar por los meandros de la corrupción, contemplamos a Cánovas del Castillo en la Vicalvarada y en el seno de la Unión Liberal, partido que, una y otra vez, pactó, gobern 6 o, al menos, convivió, tanto con los progresistas como con los demócratas que van a engendrar el Sexenio Revolucionario. Al salir de esa confusión, el partido liberalconservador recogerá, bajo la dirección de Cánovas, todo lo que sobrenadaba vivo, procedente del viejo realismo no carlista, de los moderados y de la Unión Liberal, en una nación que se transformaba. La cuestión queda clarísima en la carta de Cánovas a Martín Belda, marqués de Cabra, fechada el 28 de mayo de 1876: "De aquí a mes y medio tendremos Constitución, presupuestos y ley de Fueros, de seguro, y probablemente también organización provincial y municipal, todo en sentido más conservador y autoritario que lo teníamos al tomar el poder el último ministerio Narváez... No sé yo que después de la revolución de 1843 se lograra tanto en tan breve plazo, ni menos después de la de 1856".

Cánovas del Castillo se da perfecta cuenta de por dónde fluye el hilo de la Historia, tanto de la mundial como de la española, y parece comprender que los otros políticos no lo perciben. De ahí que considere que, por sentido de la responsabilidad, ha de aceptar la carga que se le viene encima, pero lo hace con la convicción de que hubiera sido preferible que pasase de él tan amargo cáliz, porque el problema de España, es posible que sea insoluble. Quizá por esö 'se tränsforme en un pesimista $\longrightarrow$ quizás en un realista, porque esta realidad española continuamente se le impuso- que es consciente de que se enfrenta con el trabajo de Sísifo. Los rasgos de su pesimismo son continuos. En su poema dedicado al rey Alfonso XII con motivo del fallecimiento de la Reina Mercedes — con poco estro, por cierto-, escribirá:

!Oh, pasad, esperanzas malogradas

De un pueblo sin fortuna! 
En la citada carta a Martín Belda recordará que había dicho: «Si yo logro llevar a España a Don Alfonso; si logro terminar la guerra civil; si logro reconstituir la Nación, restableciendo el ejercicio del sistema representativo; y aunque lograra también terminar la guerra de Cuba, y arreglar la Hacienda, dotando a España de un presupuesto formal... me contentaré con que no me ahorquen, simplemente». Y agrega: "Aquí me tiene usted, pues, luchando día y noche, multiplicándome, matándome, sin una ilusión, sin una esperanza, sin el menor asomo de satisfacción. Es el deber, y por serlo lo cumpliré mientras se me imponga». El 11 de noviembre de 1883, en el discurso de clausura del Congreso Español de Geografĩa Colonial y Mercantil, dirá: «...Desconfiad de los optimismos... Limitaos a aquello que es hoy hacedero, preparad lo que sea posible mañana, marchad lentamente y con grandísima prudencia, curaos de las ilusiones que os queden, no fiando a ninguna solución optimista la solución de los problemas del porvenir".

En su discurso en el Ateneo de 10 de noviembre de 1890 expondrá esta actitud de forma tajante: «Quien espere gratitud inmediata por sus servicios reales y posibles, no merece llamarse hombre de Estado. Por demás se sabe que el común de las gentes ni agradece ni aplaude sino lo que lisonjea sus vecinos intereses o la satisfacción total, que no sujeta a medida alguna, de sus pasiones".

Todo esto se deriva de un intento de análisis, con los pies muy en el suelo de nuestras posibilidades, muy fundamentalmente de las económicas, que ya le habían conducido en 1860, en sus Apuntes para la historia de Marruecos, a señalar que los hombres de Estado, "preciso es que sepan que lo son para dirigir la política y no para realizar las inspiraciones poéticas de las naciones». Todo intentó superarlo con el proteccionismo.

Existen momentos en que los políticos se definen. Antes de una fecha determinada, los vemos, incluso, a veces seguir caminos zigzagueantes. De pronto da la impresión de que encajan en la historia y, a partir de ese momento, todo pasa a ser perfectamente congruente. En el caso de Cánovas del Castillo, cuando esto se produjo, se transformó en la persona clave de los años finales de Alfonso XII y, hasta su asesinato, en la pieza esencial de la Regencia de María Cristina de Habsburgo.

En esta etapa le veremos convertido en el adalid de las doctrinas proteccionistas, sobre todo en el Discurso en defensa de la producción nacional pronunciado en el Congreso de los Diputados el día 9 de enero de 1888 por el Excmo. Sr. D. Antonio Cánovas del Castillo ${ }^{22}$. 
Este discurso es, literalmente, uno muy protector para los trigos y harinas españoles contra la concurrencia de los cereales procedentes del norte de América, de la India y de Australia, así como de «los inmensos terrenos de las pampas del Río de la Plata, que si algo nos faltare estarán destinados a empujar sobre nosotros la producción de los Estados Unidos y de la India, y a darnos, si se necesitara, el golpe de gracia". Dejando aparte una larguísima declaración incidental, interesante sólo para los tratadistas de derecho público, comenzará su intervención señalando cómo un partido conservador ha de ser proteccionista: «No ha debido pues, extrañar a nadie en la región de los principios que, dado el concepto del Estado que tiene y ha de tener necesariamente la escuela conservadora, puesto que lo es, este concepto de Estado la conduzca, como me ha conducido, no de ahora ni por motivos triviales, como los que tal vez he visto alegar en el banco del Gobierno, sino por altas y fundamentales razones científicas y políticas, a sostener y a defender siempre el derecho del Estado a intervenir, a organizar todas las funciones de la vida pública y entre otras las que se refieren a los cambios y al trabajo nacional".

La doctrina contraria es la que residencia Cánovas en la llamada "escuela individualista española", que "se alistara toda entera en las filas de la democracia más radical». Influyó ésta en la política económica de modo muy intenso; al modificarla, convenía hacerlo al modo conservador, no al revolucionario, de cambio radical y súbito. Por eso cuando el partido liberal-conservador de Cánovas llega al poder, «en esto como en todo entendió, según entenderá siempre, que si es justo y conveniente y hasta indispensable, que cada partido dirija los asuntos públicos en el sentido de sus convicciones, ha de hacerse cuando se trate de la legislación y de estados de derechos creados,... con lentitud, con moderación y a medida que las circunstancias y las necesidades lo exijan, contando siempre con que la opinión pública comienza por reconocer la necesidad de un movimiento de reacción que nunca ha de ejercitarse por medio del capricho: reacción que ningún partido de patriotismo, que ningún hombre de Estado digno de llamarse buen hijo de su Patria, realizará sin estar plenamente convencido de que aquello que va a modificar ha producido notable daño o al menos no ha producido beneficio alguno".

Así actuó el partido conservador que, "con moderación sí, pero con firmeza y con constancia, fue, poco a poco, desviando del mal camino de la libertad de comercio condenada por sus antecedentes, la legislación patria... cuya fórmula apareció, como todo el mundo sabe, en la primera ley de presupuestos de la revolución (de 1868) y en la base quinta 


\section{El inicio de la economía castiza española}

de uno de sus apéndices. Por eso uno de los primeros actos que el Gobierno conservador llevó a cabo, en virtud de las facultades extraordinarias que tenía, fue la suspensión de esa base quinta y de la revisión primera a que ella daba lugar, con lo cual afirmaba una política económica distinta de la política económica de la revolución". Recuerda que en el año 1882 , se da marcha atrás, y al volver al poder preparó «un proyecto de ley derogando totalmente dicha base quinta con el fin de entrar ...en una política económica distinta, favorable a la industria, a la agricultura, a la navegación de España..." ${ }^{23}$.

En 1888, con un Gobierno liberal que frenaba esto, se consideraba obligada la oposición conservadora a manifestar que el librecambismo, «es una doctrina que en su valor y en su rigor matemático podrá ser cierta; ...pero que no es aplicable a las naciones que están... limitadas por el momento histórico en que se encuentran y por las dificultades con que haya tropezado su desenvolvimiento; es, en suma, una doctrina irracional y atentatoria ante todo y sobre todo al principio de las nacionalidades independientes".

La prioridad en la protección la concede a la agricultura. Dirá Cánovas; "¿Dónde está el país de Europa, con su suelo gastado, con la necesidad de reemplazar las fuerzas esquilmadas de este suelo ${ }^{24}$, por medio de abonos caros y de intensos cultivos, con su alto precio en la renta de la tierra, cuya anulación o disminución representaría una revolución social y, sobre todo, con la diferencia inevitable de los jornales respecto de ciertas regiones para eso privilegiadas; ¿donde está... la Nación europea que se jacta de poder sostener la competencia? No hay ninguna».

De todo ello desciende Cánovas a la necesidad de comenzar una especie de vivísima reacción proteccionista, entonces en el caso de los cereales. Había una grave situación en el campo. El Gobierno liberal hablaba, para no tener que retocar los aranceles, de mejorar el crédito agrícola, de ayudar a través del gasto y los ingresos públicos. Cánovas del Castillo insistirá en que "se trata... de si dada la situación de la Hacienda pública, y si dada la situación de nuestros campos; del crédito, de los canales de riego, de los transportes de las obras públicas de toda naturaleza, hay o no otro medio eficaz, y sobre todo urgente, de atender al remedio de los males que padece nuestra producción, y de evitar su rápida ruina, que la reforma arancelaria».

Todo esto va a procurar hacerlo compatible con la producción industrial que se solicitaba en Cataluña. Ese difícil intento de protección integral, ese otro pacto al estilo del alemán del acero y del centeno es lo que se contiene en el ensayo publicado en el tomo III de Problemas 
Contemporáneos, titulado Necesidad de proteger a la par que la de los cereales la producción española en general. En este documento se subraya algo que después se repetirá mucho, incluyendo no sólo a Cambó, sino a Flores de Lemus; que «necesita, pues, la industria catalana, no tan sólo que se le reserve nuestro mercado agrícola, sino que se procure a todo trance su prosperidad, porque la miseria de los cultivadores sin remedio arruina a los industriales». Esta obsesión para enlazar los intereses castellanos y catalanes fue buscada sin cesar en este trabajo.

Pero además es preciso añadir al proteccionismo otro componente que viene asimismo de Alemania, y que es el populismo social. En el Discurso leído por el Excmo. Sr. D. Antonio Cánovas del Castillo el día 6 de noviembre de 1889 en el Ateneo Científico y Literario de Madrid con motivo de la apertura de sus cátedras, en el que la materia que expone la titula Algunas consideraciones sobre los modos diversos con que la soberanía se ejerce en las democracias modernas ${ }^{25}$, todo esto queda bien claro, lo cual, por otro lado, enlaza con el evidente talante de reformista social, que tiene Cánovas del Castillo, como había probado no sólo en 1883, en relación con la Comisión de Reformas Sociales, sino en multitud de textos y de actitudes, que ahora ratifica dentro de la ideología hecha patente en una declaración de Bismarck en el Reichstag —Me permito reivindicar para mí la paternidad primera de toda la política social»—, al decir: "Para mí los tiempos llegan en que un régimen político sea estimado, sobre todo, por la aptitud que posea para mantener en orden al trabajo y al capital, contribuyendo hasta donde quepa a su concierto necesario. Todos los Gobiernos rinden algún tributo ya, aunque en mayor o menor cuantía, al socialismo de Estado, bien que ninguno haya adelantado sus pasos tanto en esta senda como el alemán. Pero lo más grave ${ }^{26}$ es hoy, bien lo sabéis, que la Iglesia Católica en la propia Alemania, en Inglaterra, en Francia, y más que en ninguna parte en los Estados Unidos, rechaza, a título de una de sus principales leyes, la caridad, los excesos de la concurrencia o de la lucha por la vida en la regulación del trabajo. El Papa mismo ha declarado no ha mucho que es lícita la existencia de la formidable asociación titulada de los Caballeros del Trabajo en los Estados Unidos, con tal que respete la propiedad individual, y que no incurra en los extravíos del socialismo revolucionario. Por tales caminos ya la imayor fuerza moral que posea el mundo ${ }^{27}$, reparád támbién... que la fuerza material más triunfante en el mismo y más gloriosa ${ }^{28}$, se ha dejado persuadir del socialismo de la cátedra, del llamado inexactamente socialismo católico, del socialismo conservador, y hasta de la nueva eco- 
nomía política realista ${ }^{29}$, conformes ya en una cosa, a saber: que las leyes matemáticas de la producción y la demanda ni se deben ni se pueden aplicar a los hombres. No discuto aquí, expongo; no pretendo establecer, según dije ha poco, sino que el Estado del porvenir ha de estar influido, antes que por nada, por el hecho novísimo de que sobre los antiguos problemas políticos claramente prepondera el problema social... El más simple planteamiento de este problema dificilísimo, obligará a prescindir de gobiernos que no sean capaces de pasar irresistiblemente a un tiempo sobre las minorías propietarias o capitalistas, y sobre las mayorías trabajadoras y proletarias, con el fin de que ni las primeras aprovechen las ventajas todas de la concurrencia, ni extiendan las segundas su estricto derecho a vivir trabajando... Si... carecen las democracias de organismos proporcionados a la misión primera del Estado, si no aciertan a sobreponerse a los más, cuando haga falta, a pesar de su dependencia absoluta del número, poca duda será permitida respecto a los riesgos que correrá en sus manos el orden social... No olviden las democracias individualistas, enemigas feroces del socialismo a las veces, que está éste dentro precisamente de su propia naturaleza, porque el poder igual de todos, aunque sea un imposible práctico, pide que las consecuencias sociales para todos sean iguales también... Hoy ya el socialismo católico como el conservador, la Monarquía prusiana de derecho divino como el torysmo democrático, o sea la democracia conservadora de Disraeli y sus discípulos, ofrecen lecciones útiles para este caso, que los Estados democráticos tendrán que precipitarse a aprovechar».

La importancia, pues, de Cánovas del Castillo en la política éconómica española, no es sólo la de haber impulsado al proteccionismo, que lo impulso, sino haber adherido a él el intervencionismo estatal y un populismo social de cierta importancia. Con el proteccionismo, además intentó Cánovas ligar, al modo de Bismarck con la Prusia del centeno y la Renania del acero, a la Castilla cerealista y la Cataluña textil. Incluso resolverá —o intentará resolver - el problema vasco, tras liquidar victorioso la III Guerra Carlista, con una situación fiscal concertada a la que añadía un vigoroso proteccionismo siderometalúrgico, especialmente demandado por las Ligas Vizcaína y Guipuzcoana de Productores.

\section{El Desastre y sus efectos: un claroscuro}

Pero para conseguir que todo esto se encajase, como siempre sucede, era necesario oprimir alguna región exportadora que, con sus altas 
rentas, lo hiciese posible. Esto es lo que significa la política ultramarina de Cánovas, que va a intentar que, sobre todo, la opulenta Cuba sea la pieza que haga posible el desarrollo del conjunto de la política económica que se acaba de exponer.

De ahí que sea necesario, para que esto se entienda, exponer lo que significó económicamente este Ultramar, cuyo florón fundamental fueron las Antillas. Estas islas, con la Revolución Industrial, adquieren un papel nuevo, al formar parte de un imperio español creado dentro de un marco nacionalista y romántico concorde con tal industrialización. Es decir, este neoimperio no tiene absolutamente nada que ver con el Imperio español que, nacido a finales del siglo XV, se había terminado de esfumar con la Emancipación hispanoamericana, en los primeros años del siglo XIX. La economía imperial que, durante trescientos años, reinó en España, vive bajo otras reglas que las que se recrean sobre todo durante el reinado de Isabel II. Forma parte esta expansión colonial de un entramado que Mon y Bravo Murillo encajarán económicamente con la Península. Pio Pita Pizarro había indicado que había que explotar a Cuba como "nuestra finca".

En la economía conjunta en la que se producía este fenómeno, destacaba, conviene repetirlo, como pieza ultramarina preciadísima, Cuba, y lo hacían en menor medida Puerto Rico y Filipinas, y prácticamente nada suponían ni las posesiones situadas en los otros dos vértices del triángulo español del Pacífico con Filipinas -Marianas con Guam en el del Norte y Carolinas y Palaos, en el meridional-, ni Fernando Póo y Annobón en el Continente negro. La guerra de Africa afianza la situación como territorio español de los presidios de Ceuta y Melilla. Las disposiciones llamadas de puertos francos de Bravo Murillo originan una consolidación muy fuerte de los intereses económicos de Canarias con los de la Península:

La economía española peninsular era pobre y deseaba crecer. Al contemplar la rica isla de Cuba, e imaginarse nuestros políticos, más o menos eufóricos, que otro tanto podría suceder con Puerto Rico y con Filipinas, se unían estas ideas, con la sensación colectiva de que se había actuado en los Virreinatos americanos de manera harto generosa. De ahí que al desarrollarse un proteccionismo industrializador, que comenzó a asentarse gracias al triunfo de los moderados en 1843, se buscará un modelo que, en el fondo, lo que desea es emplear las posesiones españolas, y muy especialmente a Cuba, para enriquecer a la metrópoli. Cuba y Puerto Rico, así como Filipinas, deberían ayudar a que las industrias catalana y vasca, e incluso otros sectores protegidos, industriales, de los servicios y agrícolas, creciesen. Por supuesto, éste 
debería ser el caso de la economía cerealista castellana. En las Antillas lo que debe cosecharse no debe competir con lo que se recoge en la metrópoli. Por su productividad altísima, tendrá que ser capaz de colocar esas producciones - café, que muy pronto entrará en una franca decadencia, azúcar y tabaco en primerísimo lugar-, en los mercados internacionales, a pesar de que las compras que efectúa el Ultramar español en los mercados peninsulares, a causa de las disposiciones arancelarias proteccionistas, se verifiquen incluso a precios muy por encima de las cotizaciones internacionales. Lo mismo debería suceder con los servicios, entre los que destacan los fletes, cuestión conocida como el "asunto de la bandera». Esto es, las Antillas, dentro del régimen económico creado en el siglo XIX, tienen una relación real de intercambio que empeora progresivamente.

Inmediatamente surgen planteamientos independentistas. $\mathrm{Al}$ estudiarlos, como en el caso del puertorriqueño Hostos, e incluso en el del cubano Martí, se observa que en los primeros pasos de estos movimientos, los nacionalistas de las Antillas españolas, parecen aceptar la idea de una federación con España, siempre que se tuviera libertad en la política económica. Pero, en la concepción de entonces, que no era precisamente la de los siglos XVI y XVII, esto tenía que rechazarse. Éramos dueños de las posesiones de Ultramar, como cuestión fundamental, para extraer de ellas hasta el último real o la última peseta aprovechable. Por eso tenían que fracasar las conversaciones entre Hostos y el general Serrano, y por eso la Paz de Zanjón fue, sencillamente, una tregua. Los independentistas, en más de una ocasión, se acabaron tiñendo de anexionistas a Norteamérica. Como es bien sabido, la Confederación y el conjunto de los Estados Unidos nunca habían ocultado su deseo de comprar Cuba.

La metrópoli, sin embargo, aportaba algo muy importante a la posibilidad de que en las Antillas se generase riqueza. En primer lugar, un orden jurídico y, derivado de él, protección frente a las eventuales agresiones exteriores y, por supuesto, ante la posibilidad de un levantamiento negro, hipótesis nada despreciable tras lo sucedido en la isla de Santo Domingo.

En segundo lugar garantizaba la existencia de una masa considerable de mano de obra esclava que no fue libertada totalmente hasta 1882. Las condiciones en que trabajaban los negros esclavos eran muy duras. Se observa en el texto de Francisco de Cárdenas, Estado de la población y del trabajo en las islas de Cuba y Puerto Rico, leído en forma de informe a la Real Academia de Ciencias Morales y Políticas en las sesiones de 16 y 23 de noviembre de 1869, en el que se presenta 
la síntesis de unas muy interesantes noticias sobre el estado de la población y del trabajo en Cuba y Puerto Rico tras un interrogatorio que había sido mandado abrir por parte del Ministro de Ultramar, por Real Decreto de 25 de noviembre de 1865. En el texto de este trabajo de Cárdenas podemos observar «la triste condición a que las mismas leyes" someten a los esclavos.

Desde 1883, triunfaba la presión de la Sociedad Abolicionista, que se unía a mil planteamientos derivados del krausismo. Como consecuencia, la Administración española, tras declarar la libertad de los esclavos, se mostró incapaz de garantizar una mano de obra barata. Los lazos económicos con la metrópoli se desanudaban.

Simultáneamente, volvían a aparecer vinculaciones con una emigración empresarial y para mandos intermedios de bastante importancia, llegada de Cataluña, del resto del Levante español, incluidas las islas Baleares, y de la cornisa galaico-asturiana-montañesa. Son comerciantes, y ganan los márgenes de intermediación, sin importáriès si son españolas o foráneas las mercancías que expenden. Por tanto, no ven ventajas en la independencia, o en la anexión. Frente al Partido Liberal Autonomista en Cuba o al Partido Liberal Reformista, fundado en 1870 en Puerto Rico por Luis Muñoz Rivera y que era el partido de la "gran familia puertorriqueña" al que se afiliaban los hacendados y exportadores, estos comerciantes se vinculan en Cuba a la Unión Constitucional y en Puerto Rico al Partido Incondicional Español o Español Sin Condiciones.

Tales comerciantes españolistas, igual que los banqueros, a veces emanación de los mismos, solían ofrecer unos créditos caros, lo que irritaba aun más a los hacendados. Como a su postura se unen los funcionarios públicos, en general bastante ineficaces y muy corrompidos, la reacción de estos hacendados se endurece más'aun. Naturalmente, también esta burocracia corrompida desea que continúe todo igual.

Las grandes fincas tienen una fuerte capitalización, permitida por las economías de escala, y suelen integrarse verticalmente en los procesos de la industria alimentaria. Se aplican técnicas muy modernas: la máquina de vapor y el transporte por ferrocarril, hasta el punto de que el primer camino de hierro que existió en España fue el La Habana-Güines, en 1837. Todo esto hace nacer una Banca muy poderosa, pero también las actividades financieras enlazan con las de otros países, como las de la isla de Santomas - acepto la transliteración de Nicolás Estévanez-y, claro es, las de los propios Estados Unidos. 
Los medios de transporte llevan los productos tropicales mencionados a los cinco grandes mercados de, Estados Unidos - el esencial-, de la Península, de Gran Bretaña, de Francia y también al de Alemania, que crece con rapidez. En el de la Península, la alianza familiar del santanderino Antonio López con los Bru catalanes en la Transatlántica, introduce otro elemento de complicación en las relaciones entre Madrid y las Antillas.

El final parecía estar escrito desde 1895. Los intereses catalanes eran, como se ha señalado, cada vez más fuertes. Los grandes hacendados, a partir de 1881, con la liberación de los esclavos, veían en España poco más que una potencia que reducía sus ingresos reales. Desde el arancel Mon de 1844, habían de comprar productos y servicios peninsulares, y lo fundamental de sus ingresos, en tabaco y azúcar, se percibía en los Estados Unidos y en menor escala en otros países a precios internacionales. Cánovas daba la impresión de haber cedido ante Inglaterra en el conflicto de Joló y Borneo y ante Alemania en el asunto de las Carolinas hasta merecer aquel apóstrofe de un Costa que se daba cuenta con clarividencia de que, como vemós ahorâ,"èl eje económico del Pacífico superaría al eje económico del Atlántico: «No tienen valor (Cánovas y los otros dirigentes de la Restauración) ni para soñar». Quizá conociese Costa lo sucedido años antes con la propuesta de Sinibaldo de Mas de que ocupáramos Macao, y del abandono de la conquista de Formosa propuesta por el cónsul Cevallos.

Ahora no podía hacerse nada. Existían demasiadas contradicciones. Por una parte, se intentó paliar el problema negro con la llegada de culis chinos a Cuba tal como solicitaba el poderoso Círculo de $\mathrm{Ha}$ cendados. Pero desde 1895, no había alternativa importante al estallar de nuevo la guerra. Como señala Moreno Fraginals, ésta "nació con un cierto matiz popular, obrero y de clase media, y una fuerte campaña de captación de los sectores negro-mulatos y campesinos. Pero, casi de inmediato, tuvo el apoyo de toda la sociedad criolla incluyendo a quienes se habían alineado en el Partido Liberal Autonomista "o en el Partido Reformista, ante la ausencia de otra opción política factible». Antonio Cánovas del Castillo se quedó sin margen ninguno de maniobra. Se refugió en la expresión de combatir "hasta el último hombre y la última peseta". Si no hubiese sido asesinado, honradamente creo que no hubiera podido hacer otra cosa que intentar mantenerla.

Por lo que se refiere a Filipinas, es evidente que su significación es muchísimo más reducida que la de las Antillas. Por supuesto que antes de la Revolución Industrial ésta había sido muy grande. La economía del Extremo Oriente enlazó con la europea, a partir de aquella 
globalización económica que ya existía desde el siglo XVI, no sólo a través de portugueses y holandeses - los ingleses se incorporarían fundamentalmente desde el siglo XVIII y los franceses tenían únicamente un papel complementario-, sino del tráfico de Filipinas con América por un lado, sobre todo con Acapulco-Veracruz, y por otro con el de Filipinas con China. Pero a partir del imperio de Isabel II, sus características podrían enmarcarse en siete puntos. El primero, la alta densidad de la población malaya, con un componente complementario chino y otro religioso musulmán en muchas zonas de Filipinas, que dificultaron las posibilidades de crear una cultura homogénea hispanofilipina, capaz de consolidar los lazos económicos. La alta densidad de población planté, asimismo, problemas muy serios derivados de perturbaciones en el nivel de consumo de la misma. El segundo punto es que todo esto se complica por la existencia de cultivos tropicales con poco mercado peninsular - el abacá, el tabaco, la copra-, que tenían, sin embargo, que abrirse camino en todo el mundo. Esto explica - tercer punto- que surgiesen vinculadas a esta situación, grandes empresas capitalistas, relacionadas con grandes fincas, como ocurría, por ejemplo, con la Compañía General de Tabacos de Filipinas, las cuales se relacionaban, además, con entidades financieras importantes, como el Banco Hispano Colonial. El cuarto punto es el de la preocupación española por mantener abiertas las comunicaciones regulares con el archipiélago filipino. Esto es lo que explica la participación española en la Compañía Universal del Canal de Suez — desde 1868-1869. se percibe un complemento técnico muy interésante en esta empresay el juego de la Transatlántica en estas comunicaciones. El quinto punto se relaciona con el automático incremento del comercio exterior con la India, lo que produjo que los buques de esta carrera de Filipinas trajesen trigo que se embarcaba en puertos hindúes con destino a la Península. Cánovas del Castillo, para proteger, sobre todo a los trigueros castellanos de la cuenca del Duero, hundió este tráfico. El sexto punto viene determinado por el papel notable que en la Administración local filipina tuvieron los frailes, casi siempre con eficacia escasa, pero sí con mucha influencia, asunto complicado porque los funcionarios enviados desde España pasaron a tener un altísimo nivel de corrupción. Todo esto provocaba, en una población poco hispanizada, fenómenos crecientes de rechazo, y en los españoles que allí residían, una reacción antiseparatista fortísima, que se acabó por manifestar en relación con el proceso y ejecución de Rizal, como probó Ramón Salas Larrazábal. El séptimo punto es la importancia de Barcelona como conexión de la economía peninsular y de la filipina. 
Todo era tan frágil que, casi nada más firmada la paz de Biacna-bató, la Filipinas española se vino al suelo con celeridad. Cavite fue un punto final, sin embargo, sólo parcial, porque precisamente por las características de tales enlaces económicos, éstos no evolucionaron hacia rupturas rígidas y drásticas.

\section{La evolución final de la Regencia}

Norteamericanos, cubanos y filipinos, de consuno, deshicieron el que he llamado neoimperio colonial español de Isabel II. Aunque esto pudo parecer una tragedia también en el terreno material, ¿realmente lo fue? Conviene aclararlo.

Como se observa en el gráfico 1, basado en datos de Prados de la Escosura, en la Regencia existen dos ciclos muy claros. Uno, que se remontaba a 1883 y que iba a llegar a 1896, y otro que se inició en 1896 y que va a continuar hasta el final de este periodo histórico. El primero es depresivo; el segundo, claramente alcista, y a él corresponde 1898, aunque es evidente, por la prolongada crisis iniciada en 1883 , que si entonces se hubiesen publicado las cifras de las magnitudes macroeconómicas, se hubiese visto cómo en vez de convergencia con otros países, a lo largo del periodo 1885-1902, como muestra el gráfico 2 , se lograba divergencia. Si no se derrumbó más nuestra economía se debió, además de a las exportaciones cubanas en la primera etapa, a las exportaciones de minerales basadas en unos incrementos enormes en sus producciones, como se observa en el cuadro adjunto ${ }^{30}$.

Las producciones de minerales metálicos se dedicaban, casi en toda su integridad, a la exportación. He calculado para el mineral de hierro unas ventas al exterior de un 96 '5\% en 1887 , un ' 90 ' $2 \%$ en 1900 , un 95 ' $6 \%$ en 1902 y un 90 '3\% en 1913; para el plomo, los porcentajes de la exportación son de un 98 ' $2 \%$ en 1885 , un 89 '2\% en 1900 , un 96 ' $4 \%$ en 1902 y un 102 '3\% - al vender almacenamientos-, en 1913.

El impulso que recibió así nuestra economía es bien conocido. También se tiene noticia cumplida de la carga que significó la producción carbonífera gracias a Perpiñá Grau ${ }^{31}$. Esta composición de fuerzas expansivas - las de exportación- y contractivas - la de una energía nacional cara y de unos aranceles y mecanismos interventores de tipo cada vez más agobiador en nuestra economía de mercado- se agazapan detrás del retraso relativo que presenta nuestra economía en el periodo. 
Juan Velarde Fuertes

\begin{tabular}{|c|c|c|}
\hline \multirow{10}{*}{ 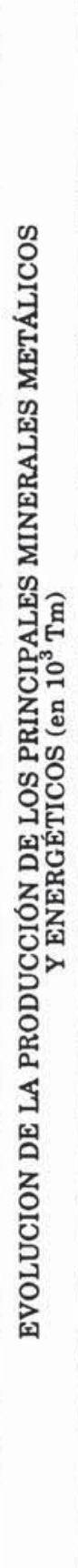 } & 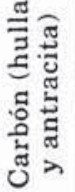 & 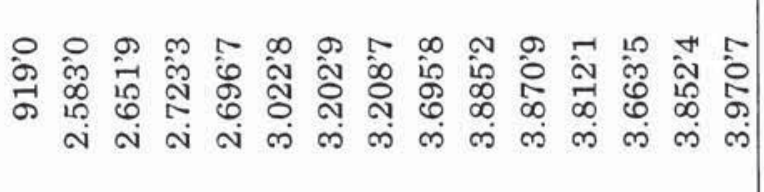 \\
\hline & 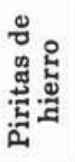 & 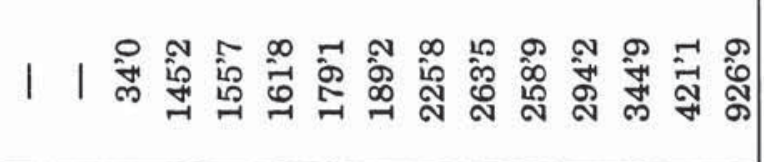 \\
\hline & 象 & 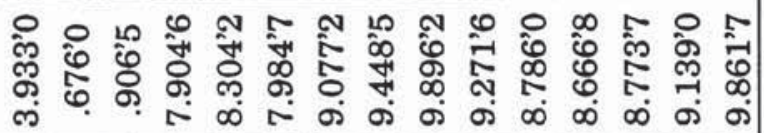 \\
\hline & $\frac{\mathrm{g}}{2}$ & 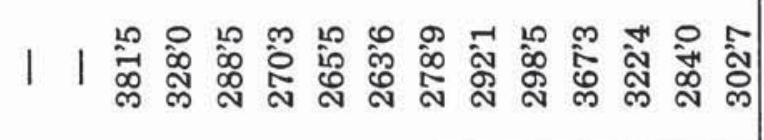 \\
\hline & 赵 & 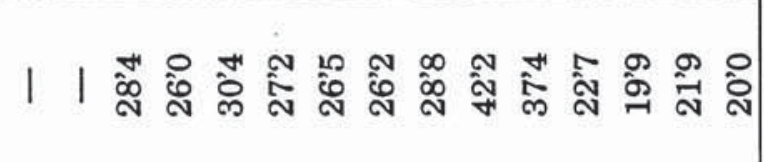 \\
\hline & 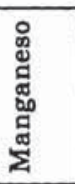 & 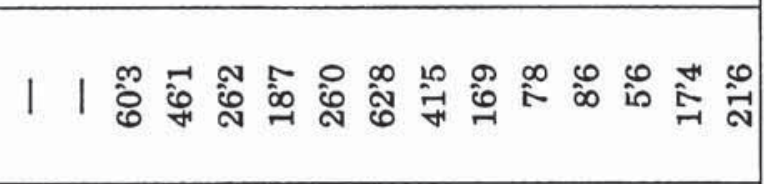 \\
\hline & 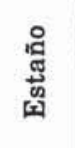 & 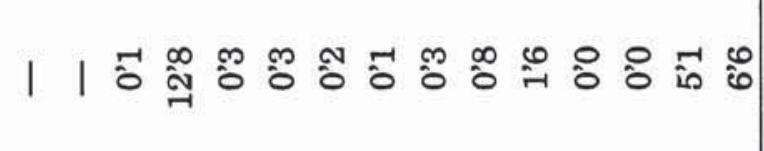 \\
\hline & 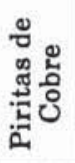 & 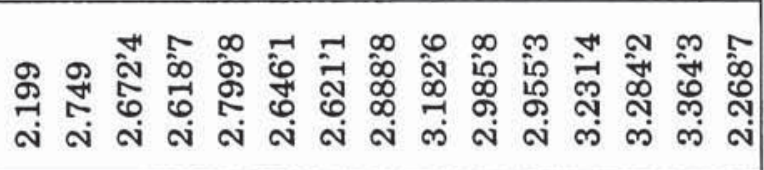 \\
\hline & 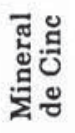 & 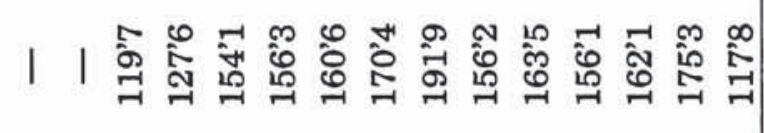 \\
\hline & 密 & 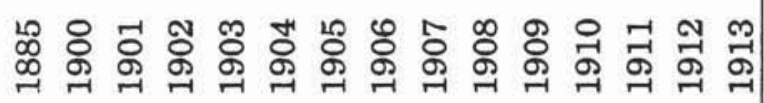 \\
\hline
\end{tabular}


El inicio de la economía castiza española

GRAFICO 1

PRODUCTO INTERIOR BRUTO POR HABITANTE

A PRECIOS DE MERCADO, ESPAÑOL, EN PESETAS 1980

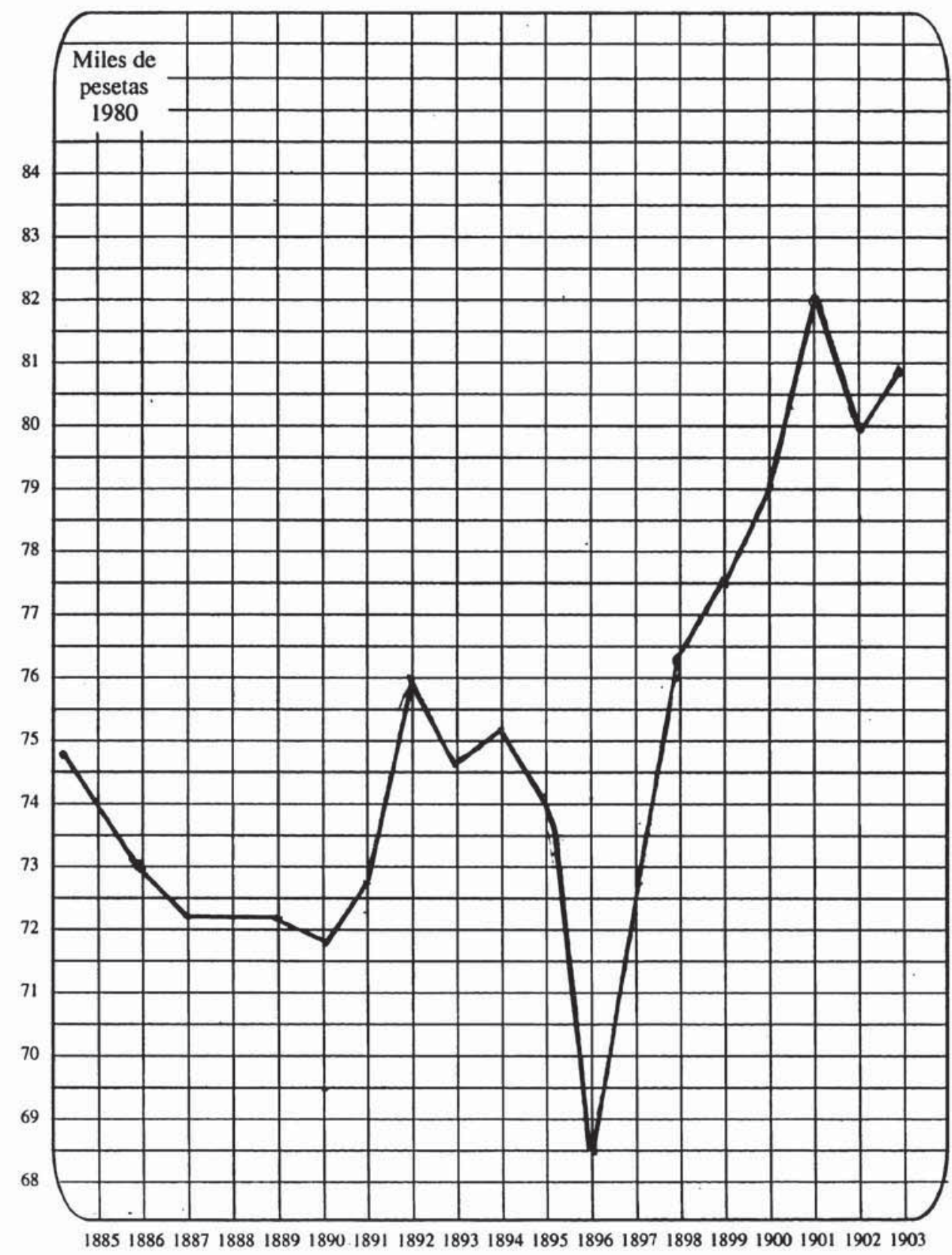




\section{Juan Velarde Fuertes}

GRÁFICO 2. PERÍODO 1885-1902

COMPARACIÓN DEL PIB REAL POR HABITANTE ESTIMADO

EN DÓLARES GEARY-KHAMIS 1990, PARA ESPAÑA $=100$

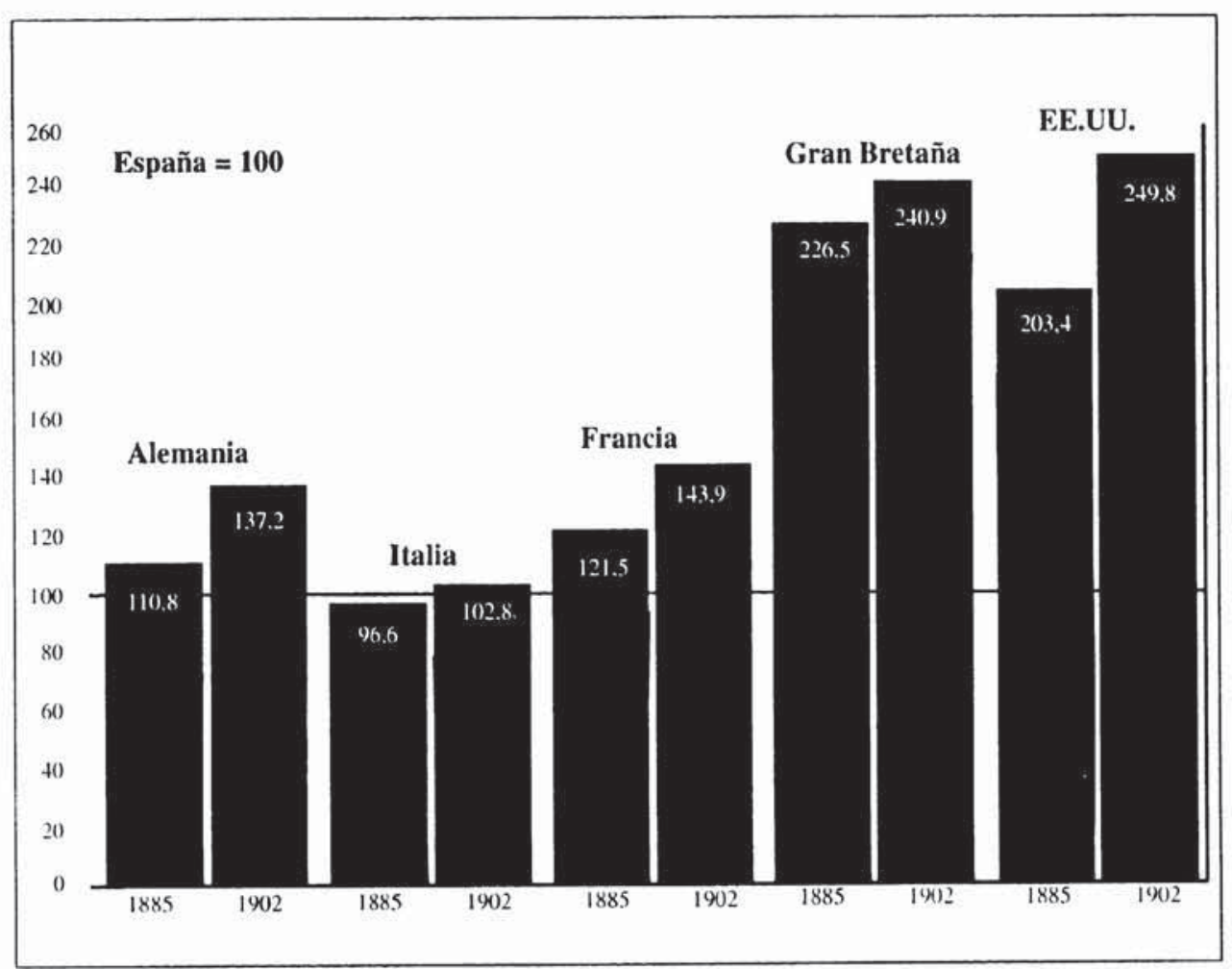

También algún efecto de tipo protector tiene que haber constituido algún año la caída del cambio de la peseta a partir de 1883, año en que se liquida cualquier conexión de la peseta con el patrón oro, pues hasta ese año, de hecho, existía libre convertibilidad en oro de nuestra moneda. Las cifras siguientes señalan la magnitud de la caída respecto a la libra esterlina y al franco francés de acuerdo con la serie 1880-1913 de Rafael Anes ${ }^{32}$. 
El inicio de la economía castiza española

\begin{tabular}{|c|c|c|c|c|c|}
\hline Años & $\begin{array}{c}\text { Pesetas por } \\
\text { libra } \\
\text { esterlina }\end{array}$ & $\begin{array}{c}\text { Pesetas por } \\
\text { franco } \\
\text { francés }\end{array}$ & Años & $\begin{array}{c}\text { Pesetas por } \\
\text { libra } \\
\text { esterlina }\end{array}$ & $\begin{array}{c}\text { Pesetas por } \\
\text { franco } \\
\text { francés }\end{array}$ \\
\hline 1880 & 24,92 & 0,9993 & 1897 & 32,61 & 1,2961 \\
1881 & 25,07 & 0,9954 & 1898 & 39,24 & 1,5416 \\
1882 & 25,65 & 1,0183 & 1899 & 31,42 & 1,2459 \\
1883 & 25,58 & 1,0156 & 1900 & 32,56 & 1,2954 \\
1884 & 25,47 & 1,0111 & 1901 & 34,78 & 1,3832 \\
1885 & 25,71 & 1,0207 & 1902 & 34,14 & 1,3583 \\
1886 & 25,70 & 1,0204 & 1903 & 33,99 & 1,3514 \\
1887 & 25,45 & 1,0104 & 1904 & 34,66 & 1,3773 \\
1888 & 25,62 & 1,0170 & 1905 & 32,91 & 1,3088 \\
1889 & 25,99 & 1,0319 & 1906 & 28,41 & 1,1288 \\
1890 & 26,31 & 1,0427 & 1907 & 28,09 & 1,1155 \\
1891 & 26,92 & 1,0669 & 1908 & 28,39 & 1,1302 \\
1892 & 29,02 & 1,1535 & 1909 & 27,15 & 1,1010 \\
1893 & 29,96 & 1,1893 & 1910 & 27,10 & 1,0714 \\
1894 & 30,11 & 1,1965 & 1911 & 27,24 & 1,0832 \\
1895 & 28,89 & 1,0459 & 1912 & 26,97 & 1,0695 \\
1896 & 30,39 & 1,2069 & 1913 & 27,09 & 1,0743 \\
\hline
\end{tabular}

No es posible decir mucho más, después de la observación de Marcela Sabaté de que, para el período 1897-1904, "la depreciación nominal de la peseta no había alcanzado a encarecer lo suficiente la moneda extranjera para compensar el abaratamiento, vía precios relativos, que simultáneamente beneficiaba a los productos foráneos en orden a su posible colocación en el mercado interno. Nuestros cálculos apuntan a que sólo la espectacular elevación del tipo de cambio nominal durante 1898 habría reforzado en la práctica, sobre los niveles de protección arancelaria establecidos en 1891, el grado de reserva del consumo aut6́ctono. En este sentido, la tesis según la cual el sistema monetario español, de corte fiduciario y tipos de cambio flexibles, habría derivado a partir de 1896 en una acentuación de las barreras de entrada del Arancel de 1891, no es correcta para el conjunto del período» ${ }^{33}$.

Como es natural las estadísticas de comercio exterior acaban por recoger el fenómeno de nuestro débil desarrollo y del cierre de nuestra economía. De 1891 a 1913, las exportaciones crecen, a precios constantes, a una tasa anual del $1 \%$. Mientras tanto, en Italia lo hacen al $4,2 \%$; 


\section{Juan Velarde Fuertes}

en Francia, al 2,8\%; en Gran Bretaña, al 3\%. Claro que, como contrapartida, las importaciones, también a precios constantes, avanzan a una escuálida tasa anual del $0,04 \%$, mientras que en Italia el crecimiento es del 5,5\%; en Francia, del 2,6\% y en Gran Bretaña, del $2,6 \%$ también. Desde el inicio de la Regencia y hasta 1913, la balanza de mercancías presenta los siguientes saldos (E-I ${ }^{34}$.

\begin{tabular}{|c|c|c|c|}
\hline Años & $\begin{array}{c}\text { Superávit }(+) \text { o déficit }(-) \\
\text { en } 10^{6} \text { pesetas corrientes }\end{array}$ & Años & $\begin{array}{c}\text { Superávit }(+) \text { o déficit }(-) \\
\text { en } 10^{6} \text { pesetas corrientes } 1885\end{array}$ \\
\hline 1885 & $+70,6$ & 1900 & $+132,2$ \\
1886 & $+97,5$ & 1901 & $+15,3$ \\
1887 & $+70,5$ & 1902 & $+52,8$ \\
1888 & $+141,1$ & 1903 & $+16,0$ \\
1889 & $+23,8$ & 1904 & $+73,6$ \\
1890 & $+31,5$ & 1905 & $+73,3$ \\
1891 & $+220,4$ & 1906 & $+296,7$ \\
1892 & $+354,6$ & 1907 & $+297,6$ \\
1893 & $+291,2$ & 1908 & $+151,0$ \\
1894 & $+149,4$ & 1909 & $+178,1$ \\
1895 & $+207,7$ & 1910 & $+163,1$ \\
1896 & $+437,7$ & 1911 & $+176,1$ \\
1897 & $+447,3$ & 1012 & $+160,1$ \\
1898 & $+488,1$ & 1913 & $-28,3$ \\
1899 & $+63,5$ & & \\
\hline
\end{tabular}

Se debe completar este cuadro, a efectos de tener una idea aproximada de las balanzas exteriores del período, en primer lugar con las remesas de fondos de América, al liquidarse multitud de negocios en el Caribe, como consecuencia de la catástrofe de 1898 y por otra serie de sucesos, entre los que se encuentran desde el fin del porfiriato en México, que tuvo lugar en 1911, hasta el crecimiento acelerado que en esta etapa presentaba la economía argentina, lo que facilitaba la remesa de cantidades muy importantes desde el Plata hacia España. En segundo lugar, con el envío de fondos por parte de la Iglesia católica desde Francia a España, relacionados con el anticlerical asunto de los mil millones ${ }^{35}$ que tuvo consecuencias sociopolíticas muy importantes en el país vecino ${ }^{36}$. Saldos favorables en la balanza de mercancías y estas llegadas de fondos permiten iniciar una activa política de rescate de activos en manos 
El inicio de la economía castiza española

extranjeras, al mismo tiempo que se incrementa la reserva de oro del Banco de España, y que se hace posible la inversión en un sector nuevo, el de la hidroelectricidad, al ser posible el transporte de la energía eléctrica a largas distancias al descubrirse la corriente alterna.

No se debe olvidar tampoco, para explicar la situación en la última parte de la Regencia, que el siglo XX entró bajo la influencia de un político importantísimo por los resultados que va a dar desde el punto de vista de la economía, Raimundo Fernández Villaverde. Este ministro se encuentra con un hecho que es básico y fundamental. Si contemplamos el balance del Banco de España cuando está acabando el siglo XIX y, por supuesto, en el momento en que se produce el fracaso del 98, vemos que en el activo existe una cifra muy alta de anticipos entregados al Tesoro. Tales anticipos se debían a que el sistema tributario no era capaz de recaudar todo lo que la guerra en el Caribe, en el Pacífico, y con los EEUU, exigía. Este hecho fundamental, y claro es, estos anticipos que concede el Banco al Tesoro, en encuentran en el activo del Banco. En el pasivo se anota el incremento de la circulación fiduciaria. La más somera comprobación de las cifras mostraba que eran muy altas las sumas prestadas por nuestro Banco emisor. Era necesario poder reducir tan considerable débito de la Hacienda Pública. Para ello era preciso tranquilizar los mercados porque se sospechaba que el Tesoro español no iba a ser capaz de pagar los intereses de la Deuda acumulada, de devolver los préstamos al Banco de España y, para conseguir ambas cosas, de reducir los gastos y aumentar los ingresos. El esfuerzo que está detrás constituye la base de la política económica de Villaverde.

Tuvo especial relieve su incremento de los impuestos, por generar una protesta gigantesca. Por el lado de los gastos, Villaverde inicia una política de economías. Es necesario no gastar más que aquello verdaderamente imprescindible para el Estado. Es el inicio de una época donde el equilibrio se va a alcanzar por el lado, no sólo de los ingresos, sino con especial fuerza de los gastos. Detrás de esto pronto surgirá la frase de Echegaray del "santo temor al déficit». Así se logró pasar a situación de superávit, pero, al devolver los préstamos, parecería que iba a reducirse la circulación fiduciaria, o sea, en aquellos tiempos, lo esencial de la oferta monetaria. Esta política, en aquel momento de restricción del gasto público, hubiera supuesto que el aparato económico español sufriese un frenazo tremendo. Hubiésemos tenido, superpuestos, el fracaso político en el exterior, con las derrotas del Caribe y Filipinas, aparte de con Estados Unidos, y el fracaso económico en el interior, al surgir una situación contractiva. 
Sin embargo este fracaso no se produjo porque el Banco de España cambió su activo, al empezar a conceder créditos a la banca privada; esto es, se convirtió de hecho en un Banco de bancos. A partir de ahí ha surgido otra situación complementaria, que venía determinada porque, como se señala un poco más arriba, había terminado nuestra presencia en Ultramar y muchos comerciantes y personas adineradas, decidieron liquidar sus negocios en América y Filipinas y traer esos fondos a España. En aquel momento, por consiguiente, el Banco de España empieza a prestar a los bancos, pero los bancos, en parte notable, empiezan a ser fundados o ampliados, porque esos capitales que, como se ha indicado, venían de América, se refugian precisamente en ellos e incluso, como también se repatrian empresarios, éstos los fundan. Agreguemos que, aparte de los americanos, llegan otros capitales y que la industria se encuentra con que tiene una especie de malla protectora tremenda contra cualquier competencia del exterior. Invertir en los sectores industriales más diversos tiene muy poco riesgo porque está reservado para ellos el mercado español.

La última característica de la etapa es que se produce la fuerte exportación ya señalada de minerales de hierro de Vascongadás hacia Gran Bretaña. Esa exportación de mineral no estaba controlada significativamente por compañías extranjeras; es más, la mayoría se encontraba explotada por mineros españoles. Ese mineral era transportado a Inglaterra en parte notable por buques españoles, que se había construido en astilleros españoles. En la zona de Bilbao se crea un conjunto de beneficios para los habitantes de la zona, para los dueños de los establecimientos mineros y para los trabajadores. Esto va a convertir a Bilbao en una plaza financiera creciente.

Así es como se explica la creación y la difusión de un conjunto amplísimo de bancos que constituye el meollo esencial de la banca actual. Si los anotamos cronológicamente, el primero de ellos es el Banco Guipuzcoano que nace en 1898; a continuación, en ese mismo año, se crea el Banco Asturiano de Industria y Comercio, y en Asturias nace también el Banco de Gijón, con capital que viene de América: En el año 1900 aparece el Banco de Valencia, y también el Banco Hispano Americano, que recibe este nombre no porque vaya esencialmente a actuar en Hispanoamérica, sino porque los capitales que lo constituyen vienen casi todos de antiguos residentes hispanoamericanos. Otro banco de 1900 es el Banco Castellano, que opera en Valladolid. En el año 1901 aparece en la zona vasca el segundo gran banco de la villa de Bilbao, el Banco de Vizcaya. En el año 1902 se transforma 
el Crédito Mobiliario Español en el Banco Español de Crédito (Banesto). Esa serie de creaciones de bancos surge también dentro de una atmósfera creciente de nacionalismo económico. Hay que eliminar la presencia de capitales extranjeros y tienen éstos que ser sustituidos por capitales nacionales gracias a la acción de esos bancos que actúan, por supuesto, como fuente de nuestra industrialización. Así es como aparece el llamado capitalismo nacional, un nombre que se recibe de Ortega y Gasset. Actúa en todos los sectores y es enemigo del capitalismo extranjero.

\section{Reflexión desde 1998}

La Regencia había imitado el modelo alemán. Teníamos un fuerte proteccionismo. La cartelización, a partir de la fundación de la Unión Española de Explosivos, pasó a tener carta de naturaleza entre nosotros. La Banca mixta quedó fuertemente organizada. El Estado practicaba un creciente intervencionismo. Se puso en marcha un aspecto concreto de éste para resolver la cuestión obrera. No teníamos patrón oro, sino un modelo fiduciario plata. El conjunto, con grandes altibajos, avanzaba, pero con débiles tasas de desarrollo, que nos apartaban cada vez más de los niveles de ingresos de los ciudadanos de las grandes potencias.

La gran conmoción de 1898 iba, pues, a resultar acompañada de otra reptante, que frenaba el desarrollo de nuestra economía. Nuestros intelectuales intuyeron algo de esto, pero más de una vez, después de decir, se desdijeron. No entendieron nada del proceso económico. Los grupos de presión se zambulleron gozosos en el lodazal así creado, y en general crecieron de modo magnífico, claro que a expensas del bienestar general. Los políticos nada hicieron para cambiar las cosas, quizá porque no tenían la menor idea clara de por dónde podrían empezar tales cambios. Cuando en los años cincuenta se intentó con este modelo un fuerte desarrollo, se observó con espanto que, literalmente, se desbarajustaba.

Por eso, desde 1959 estamos empeñados los españoles en la liquidación de la economía que nació con la Regencia. Con ello se pierde más de un símbolo romántico, pero no existe otra opción, salvo la de un futuro miserable. Incluso para los que lamentan estas pérdidas simbólicas, parece adecuado a lo que ahora se contempla lo que dijo un poeta gongorino del siglo XVIII, José Antonio Porcel y Salablanca en su Canción heroica, dedicada a los reyes Fernando VI y Bárbara de Braganza: 
Ya al sepultado sol digno tributo

de lágrimas rendisteis...;

Ahora bañad el aire de armonía,

los pechos desatad en alegría;

que ya, a pesar del tenebroso luto

vuelve (el sol), de luz su esfera coronando.

España, efectivamente, ha sufrido un largo y tenebroso luto a partir de 1898. Da la impresión de que ahora, al entrar, junto con un pequeño grupo de países europeos, en la tercera fase de la Unión Económica y Monetaria a partir del 3 de mayo de 1998 - exactamente al conmemorarse el centenario de la batalla naval de Cavite-, estamos a punto de que el sol vuelva a nacer y de que, gracias a la economía, todo haya dado, al fin, un giro, porque parece haber resultado cierto aquello que decía Gonzalo de Berceo en La vida de San Millán:

Mientre el siegle sea é durare Espanna.

\section{Notas}

1 El artículo de Nicolai Dmitrievich Kondratief, Los grandes ciclos económicos, aparecido en Voprosy Konyuntury, 1928, vol. I, págs. 28-79, fue traducido al inglés en The Review of Economics and Statistics, 1935, vol. 17, n1 6, págs. 105-115. Junto con el trabajo de G. Garvy, Kondratieff's theory of long waves, publicado en The Review of Economics and Statistics, 1943, vol. 25, n1 4, págs. 203-219, fue traducido al español en el volumen Las ondas largas de la economia, Revista de Occidente, Madrid.

2 Un buen panorama de esta crisis en Johan Åkerman, Structures et cycles économiques, trad. de Béatrice Marchal y G. Augot, Presses Universitaires de France, Paris, 1957, Tomo II, parte I, págs. 349-385. Soy consciente de que de esta obra de Åkerman existe una versión española; su traducción es tan deficiente que nadie puede aconsejar su manejo.

3 Sigue teniendo actualidad lo que sobre este fenómeno señala E.A.G. Robinson en Monopolio, traducción de Víctor L. Urquidi, 20 edición, Fondo de Cultura Económica, México D.F., 1950, págs. 148-158.

4 Cfr. de J. Bouvier, tanto Le Krach de L'Union Générale, 1960, como Le Crédit Lyonnais de 1863 à 1882. Les années de formation d'une banque de dépots, 1961.

5 Cfr. Guy P. Palmade, Capitalisme et capitalistes français au XIXe siècle, Armand Colin, Paris, 1961, págs. 232-235.

6 Como señala Robert Liefmann en Kartelle, Konzerne und Trusts, 80 edición, Stuttgart, 1930 (la traducción inglesa, New York, 1933), el término cártel se utilizó por primera vez el 5 de mayo de 1879, en una sesión del Reichstag. Se empléó ese 


\section{El inicio de la economía castiza española}

término para designar la situación creada por los productores de material ferroviario fijo y móvil que, al controlar el mercado, hacían pagar a los consumidores alemanes precios más elevados que a los consumidores extranjeros.

7 En el ensayo Das Kartellproblem in Lichte der Deustchen Kartelliteratur, en los Schriften de la Verein für Sozialpolitik, 1931, vol. 180, parte 2.

8 Cfs. la pág 237 de su artículo Das Verhältnis der Kartelle zum Staate, en los Schriften de la Verein für Sozialpolitik, 1905, vol. 116; más adelante, véase el número monográfico Das Kartellproblem, en los Schriften de la Verein für Sozialpolitik.

9 En Behemoth. Pensamiento y acción en el nacional-socialismo, traducción de Vicente Herrero y Javier Márquez, Fondo de Cultura-Económica, México, 1943, pág. 300 .

10 Macmillan, London, 1919.

11 En Journal of Political Economy, febrero 1964, vol. 72, n1 1, págs. 44-61.

12 Cfs. Franz Neumann, Behemoth, ibidem.

13 En Die Praxis des Zwangskartellgesetzes, en Zeitschrift für die gesamte Staatswissenschft, 1937, vol. 97, pág. 500.

14 En Carteles Internacionales, traducción de Samuel Cosío Villegas, Fondo de Cultura Económica, México D.F., 1950, pág. 23.

15 Cfr. Johan Åkerman, ob. cit., tomo II, parte I, pág. 308.

16 Las tasas proceden del cuadro 5.1., Tasas de crecimiento de los IPI de algunos patses europeos, $1831-1980$ (porcentaje), en el ensayo de Albert Carreras, La industria, en el vol. Estadisticas históricas de España. siglos XIX-XX, coordinación de Albert Carreras, Fundación Banco Exterior, Madrid, 1989, pág. 174.

17 Cfs. Antonio Ramos Oliveira, Historia social y politica de Alemania, tomo I, 20 edición, Fondo de Cultura Económica, México D.F., 1952, pág. 212.

$18 \mathrm{El}$ papel de List en el lanzamiento y defensa ,de la Zollverein, puede verse en The life of Friedrich List and selection from his wrintings, ed. por M.E. Hirst; Smith, Elder \& Co., London, 1909.

19 Cfs. Joseph A. Schumpeter, Historia del análisis económico, traducción de Manuel Sacristán con la colaboración de José A. García Durán y Narciso Serra, Ariel, Esplugues de Llobregat, 1971, pág. 566.

20 Del ensayo La industria cit. de Albert Carreras, ibidem.

21. Johan Åkerman, ob. cit., tomo II, parte I, pág. 325.

22 Se publicó en un volumen de un centenar de páginas, en Madrid, en 1888, en la Librería de Miguel Guijarro, con la indicación: "Publicado por acuerdo del partido", liberal-conservador se entiende. Por eso contiene, aparte del discurso de Cánovas, el texto de la proposición de Ley de la que éste es primer firmante - tras él lo hacen el Conde de Toreno, Francisco Silvela, Raimundo Fernández Villaverde, el vizconde de Campo Grande, el marqués de Pidal y Fernando Cos-Gayón-,-el 2 de diciembre de 1887, así como los señores que dijeron no y aquellos que votaron sí a la misma, agregando que es evidente que hubo un "número considerable" de abstenciones. La proposición de ley colocaba al partido liberal, en una posición difícil ante los labradores, que vivían momentos de mucha dificultad.

23 Una actitud conservadora puede ser asumida por un partido progresista o por uno conservador; también una actitud revolucionaria puede ser de un partido conservador o progresista. En la siguiente matriz se intenta dejar todo esto claro: 


\begin{tabular}{|c|c|c|}
\hline \multirow{2}{*}{ Partidos } & \multicolumn{2}{|c|}{ Talantes } \\
\hline & Conservador & Revolucionario \\
\hline Conservador & Cánovas & Maura \\
\hline Progresista & Sagasta & Figuerola \\
\hline
\end{tabular}

24 A los de España los denominará «los secos y casi estériles de España”, muy influido por Los males de la Patria y la revolución española, de Lucas Mallada, como recalcará en la pág. 44 , al calificar a la realidad española como "una de las menos aventajadas bajo el punto de vista material».

25 Imprenta de A. Pérez Dubrull, Madrid, 1889.

26 Transcribo literalmente, como es lógico, pero esta expresión "pero lo más grave", es inverosímil en la pluma de Cánovas. No sólo por su devoción a la Iglesia, sino porque comulgaba con la orientación que seguía en este sentido Leon XIII. Muy probablemente en vez de grave, pensó en escribir, si lo escribió, importante, significativo, o cosa parecida. Después apareció esto dentro de un texto muy barroco - como solía redactar Cánovas, no sé si por influencias de la literatura del siglo XVII que tan bien conocía- y, de acuerdo con un texto de Menéndez y Pelayo sobre él, muy probablemente escrito de modo "atropellado", y así llega a nosotros, pero no se le puede despachar hacia el futuro sin esta observación.

27 Evidentemente la Iglesia Católica.

28 Parece que, el recién nacido Imperio alemán.

29 No puede dejar de subrayarse la muy oportuna referencia a la batalla del método que inmediatamente recogerá Cánovas.

30 Las series de minerales se contienen, por una parte, en el volumen Estadísticas básicas de España. 1900-1970, Confederación Española de Cajas de Ahorros, Madrid, 1975, págs. 186-187 y 192-197; en carbón y hierro enlazan perfectamente estas series con las de La Industria de Albert Carreras, loc. cit., págs. 194-195 y 201-202; sin embargo no sucede así con las demás. Me parece que la serie más completa, es, la de las Estadisticas básicas de España, cit., que comenta, para las series de los minerales de cinc, cobre, estaño, manganeso, mercurio y plomo, que «son de las más completas" y que «no existen lagunas importantes, aunque sí modificaciones en el criterio de clasificación de los datos". Debe tenerse en cuenta que la serie de carbones de Albert Carreras, sin señalar nada, elimina el lignito; por tanto, para homogeneizar, así se hace. De todas formas, la producción de lignito en el período fue pequeña - oscila entre 47.934 toneladas en 1901 y 138.396 toneladas en 1913 según Estadísticas básicas... y entre 26.000 y 277.000 para ambas fechas según Estadísticas históricas...- que da la impresión de que encubren, con su diferencia, algún tipo de conversión en TEC, porque en antracita y hulla, 1 TEC $\circ 1 \mathrm{tm}$, y en lignito, $1 \mathrm{tm}$ o 0 '5 TEC. La serie de producción de piritas, desglosada, procede de Estadísticas básicas... pero como se inicia la serie en 1901, los datos de 1885 y 1900 se toman de Estadísticas históricas... y se asignan a piritas de cobre, porque las de hierro tenían entonces una significación minúscula: en 1901, un 1'3\%.

31 Cfs. Román Perpiñá Grau, Memorandum sobre la política del carbón, CEEV, Valencia, 1935.

32 Cfs. Rafael Anes, El Banco de España 1874-1914: un Banco nacional, en La Banca española en la Restauración, volumen I. 


\section{El inicio de la economía castiza española}

33 La protección se dirige a ciertos bienes concretos; la inseguridad de los índices de precios en cuanto señal de los de movimiento de cada mercancía concreta, y más en los de entonces, motiva que ni se pueda hablar del modo rotundo que señalan Maluquer de Motes y Prados de la Escosura, en sentido de complemento proteccionista, ni en el ofrecido por Marcela Sabaté, de crítica radical a esta postura. Debe continuarse esta difícil investigación para dilucidar si existe convergencia, o no, entre política arancelaria y movimientos del cambio. Creo que alguna convergencia hubo, y no sólo en los años de caída más exagerada de la peseta. Véase, como punto de arranque de esta posible polémica, el artículo de Marcela Sabaté Sort, Tipo de cambio y protección en la economía española de principios de siglo, en Revista de Economía Aplicada, primavera 1993 , vol. 1 , n. ${ }^{\circ} 1$, págs. 67-86.

34 La base estadística procede de Antonio Tena, en Comercio exterior, en Estadisticas historicas de España, ob. cit. págs. 335 y 342-343. Naturalmente, estos saldos estimados, nada, o poquísimo, tienen que ver con los oficiales, en los que se ampara esta perezosa afirmación del déficit sistemático de nuestra balanza comercial.

35 En 1898, el Consejo de la Orden de la Francmasonería, dentro de la obediencia del Gran Oriente de Francia, difundió en las Logias un texto, reproducido en el Bulletin hebdomaire des travaux de la Maçonnerie en France, 29 de abril de 1898, en el que se incluía "la carta gráfica del aumento de los bienes inmuebles conocidos de las congregaciones religiosas desde 1881 a $1898 \ldots$ A partir de 1881 , fecha de aplicación de los decretos denominados del 29 de marzo, los inmuebles ocupados por las congregaciones... han subido de 800 millones a 2 mil millones (de francos), teniendo sólo en cuenta bienes conocidos, porque si se tienen en cuenta los que retienen las congregaciones, se llegaría a los 10 mil millones...*

36 A mi juicio, el clima está bien recogido en Pierre Chevallier, Histoire de la Franc-Maçonnerie française, tomo III, La Maçonnerie: Eglise de la République (18771944), Fayard, s.l., 1975, pág. 71-117. 